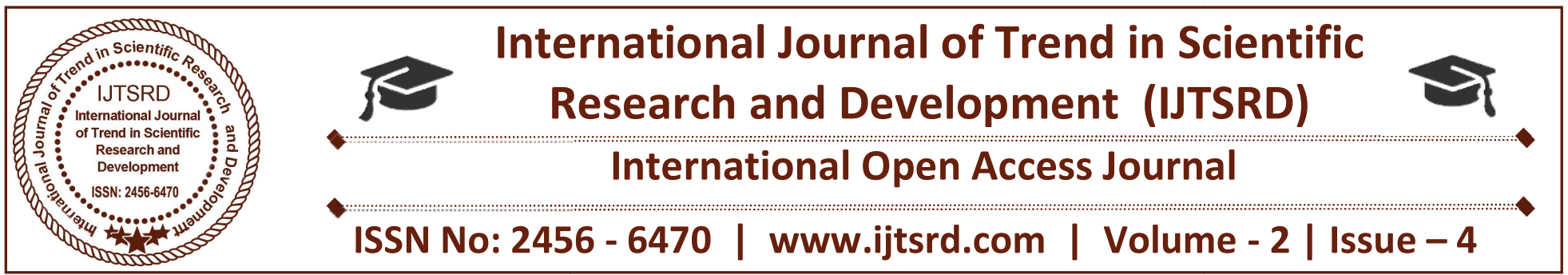

\title{
Grievance Handling Procedure a case of Soft Zeal Technology Pvt. Ltd, Pune
}

\author{
Supriya Bhagat ${ }^{1}$, Ms. Gagandeep Virdi ${ }^{2}$, Roshen Raju ${ }^{1}$ \\ ${ }^{1}$ Assistant Professor, ${ }^{2}$ Student \\ ${ }^{1,2}$ Sadhu Vaswani Institute of Management Studies, Pune, Maharashtra, India
}

\section{ABSTRACT}

This research paper focuses on the grievance handling procedure at Soft Zeal Technology Pvt. Ltd .Pune. Maharashtra. The objective of this paper is to determine the effective handling of the grievances faced by the employee. The study identifies the most common factors for arising the grievances at the place of employment. The study also looks for the root of grievance faced by an employee, grievance handling techniques, and the management procedures of resolving the grievances.

Keywords: Grievance, Grievance Handling Techniques, process, policy

\section{INTRODUCTION}

Soft Zeal helps organizations to realize ways to address their business problems. Listening is key to getting it right. We work closely with and are accountable to our customers' business stakeholders, enabling us to deliver an optimal result. We emphasis communication: keeping customers informed of our process, listening to their feedback, and preparing documentation that clearly reflects their requirements. This approach guarantees consistent, effective and efficient delivery of services that are tailored to the nature and scale of each assignment.

So, when managing a total lifecycle project or performing a short-term consultancy, we meet the differing needs of our stakeholders. The full resources of Soft Zeal are dedicated to ensuring that every engagement is successful.

\section{NEED OF THE STUDY}

Employees differ as individuals in their needs, expectations and behavior. When their needs are not satisfied or their objectives are not achieved, the result is employee dissatisfaction. It is not an easy task for the management to keep all the employees satisfied and motivated, all the time.

Any emotional, physical or mental dissatisfaction of an employee if gets unattended it leads to remorse and discontentment. The small issues if not settled properly leads to higher degree of dissatisfaction towards the work. This type of attitude among the employee is very harmful as it creates negativity among everyone. As people share or express their woes. It spreads and creates illusion among others too. Hence it is very much necessary to solve or address the employee grievances on time to eradicate the irritations which is likely to increase and lead to unfavorable attitude towards the management and unhealthy relations in the organization. Hence, handling the grievances of any person in any organization is of great importance.

This forms the need for the study of the grievance redressal procedure of the organization and its effectiveness towards job satisfaction to maintain healthy and harmonious environment of the organization. The main focus of this revolves around the bottom level of management

OBJECTIVES OF THE STUDY 
- To study the effectiveness of Grievance Handling Procedure

- To identify whether the employees are aware of the grievance handling procedure.

- To know the level of satisfaction towards the grievance handling procedure of the organization.

\section{RESEARCH METHODOLOGY}

A Research is a careful study or inquiry; especially thorough search for new facts in any branch of knowledge. It is a systemized effort to gain more knowledge. 'Research methodology is a way to systematically solve the research problem. It may be understood as a science of studying how research is done scientifically. It is essential for the investigator to know not only the research methods or procedures but also the methodology.

\section{TYPE OF RESEARCH}

The type of research used in this project is descriptive in nature.

\section{DATA COLLECTION METHOD}

Data was collected using Questionnaire. A questionnaire consists of a number of questions involving both specific and general question related to the study topic.

\section{SOURCES OF DATA}

GRIEVANCE HANDLING PROCEDURE at SOFT ZEAL

Grievance procedure:

1. They allow employees and management to resolve problems

2. They allow employees to voice concerns workplace and environment

3. They keep lines of communication open

How do they prevent a grievance?

1. Identify potential causes

2. Correct problems promptly

3. Encourage corrective suggestions

4. Communicate and give advance notice of change

5. Learn to listen

6. Be consistent

If they receive an employee grievance

First and foremost

1. Takes charge

2. Consider the possibility of early settlement

There are two sources of data namely

\section{PRIMARY DATA}

\section{Grievance timelines:}

Any grievance not answered within the time limits specified is submitted to the next step (employee)

Primary data are fresh data which are collected through survey from the employees using questionnaire.

\section{SECONDARY DATA}

Secondary data are from books, internet, and reports.

\section{SAMPLING TECHNIQUE:}

Sampling Design: Convenience sampling technique is used for the study. For the pilot survey, a sample size of 30 respondents is taken into an account

Sampling Unit: The sampling unit is limited to the employees of softzeal technology

Any grievance which is not appealed to the next succeeding step in writing within the specific time limits specified is considered withdrawn and not eligible for further appeal (management)

\section{Steps in grievance process}

The number of steps grievance process contains the following:

- Oral grievance

- Written grievance

- Grievance advanced to employee / industrial relations 
- Arbitration

\section{Steps in oral grievance process}

Employee conveys oral grievance to his direct boss within the time frame as specified in the company policies

Immediate supervisor provides written response to the oral grievance within timeframe

\section{Steps in written grievance process}

If the oral grievance is not satisfactory adjusted:

The person submits the grievance in writing to the department head on a grievance form signed by the employee and the grievance must be submitted in writing within the time frame which is as specified in the company grievance policy

Then the department arranges a grievance meeting between the department and the grievant

Steps in - grievance Advanced to employee/ labor relations

If the matter is not satisfactory adjusted in previous written step or an answer has not been given

Then the written grievance previously submitted is forwarded to the Human Resource Department

\section{DATA ANALYSIS AND INTERPRETATION}

\section{Questions:}

1. Are you aware of the grievance redressal committee of your company?

A. Yes

B. No

\begin{tabular}{|l|l|}
\hline A. es & 24 \\
\hline B. No & 6 \\
\hline
\end{tabular}

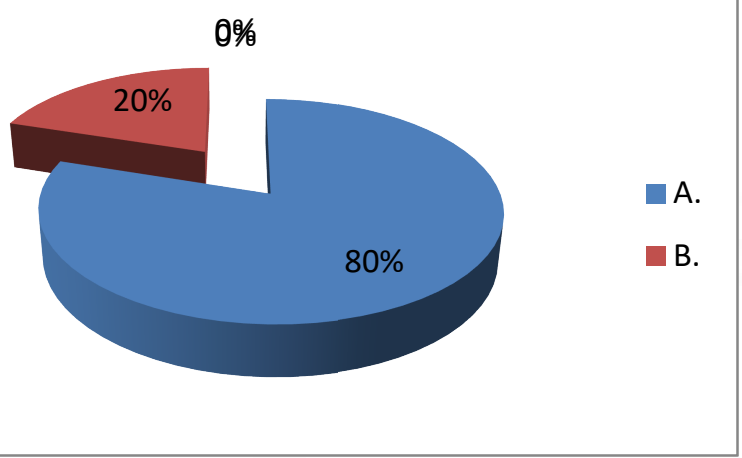

Interpretation:

From the above chart it can be analyzed that:

$20 \%$ of employees are not aware of the redressal committee of the company

$80 \%$ of the employees are aware of the redressal committee of the company

2. Are you aware of the members of the grievance redressal committee?
A. Yes

B. No

\begin{tabular}{|c|c|c|}
\hline A. YES & 3 & 24 \\
B. NO & 0 & 6 \\
ment
\end{tabular}

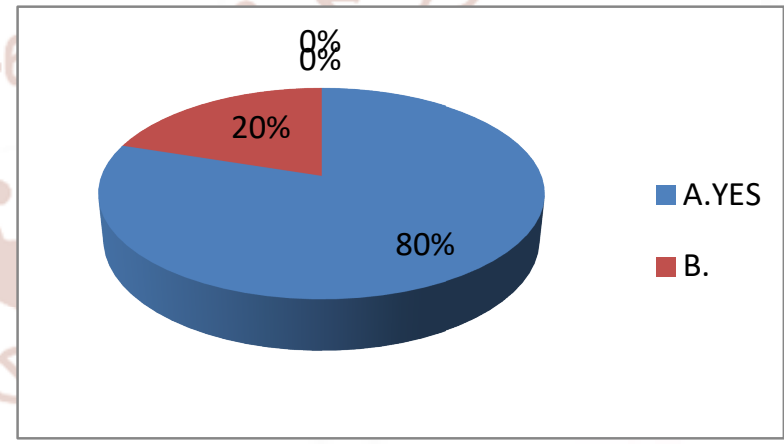

\section{Interpretation:}

From the above chart it can be analyzed that:

$20 \%$ of the employees are not aware of the members of the grievance redressal committee

$80 \%$ of the employees are aware of the members of the grievance redressal committee

3. Are you aware of the monthly meetings of the grievance redressal committee which are being held? 

A. Yes
B. No

\begin{tabular}{|l|l|}
\hline A. YES & 20 \\
\hline B NO & 10 \\
\hline
\end{tabular}

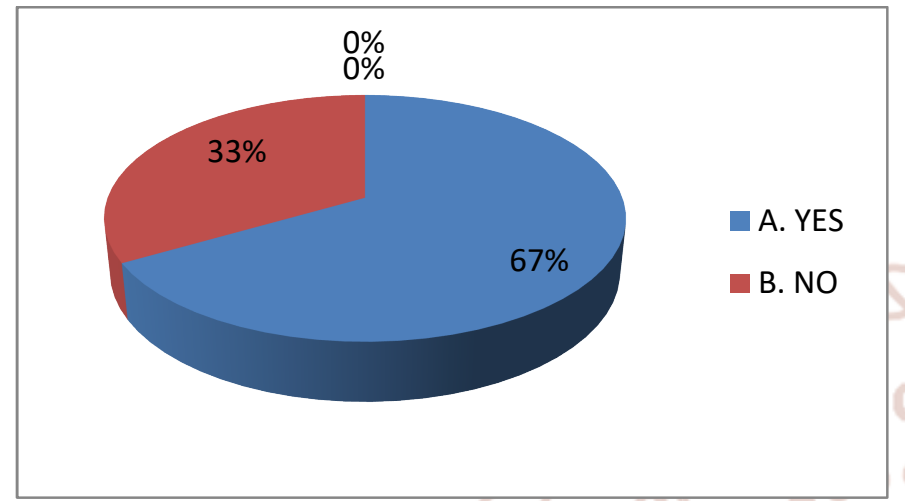

\section{Interpretation:}

From the above chart it can be analyzed that:

$33 \%$ of the employees are not aware of the monthly meetings of the grievance redressal committee which are being held

$67 \%$ of the employees are aware of the monthly meetings of the grievance redressal committee which are being held

4. Is the real basis of your problem identified?
A. Agree
B. Disagree

\begin{tabular}{|l|l|}
\hline A. AGREE & 24 \\
\hline B. DISAGREE & 6 \\
\hline
\end{tabular}

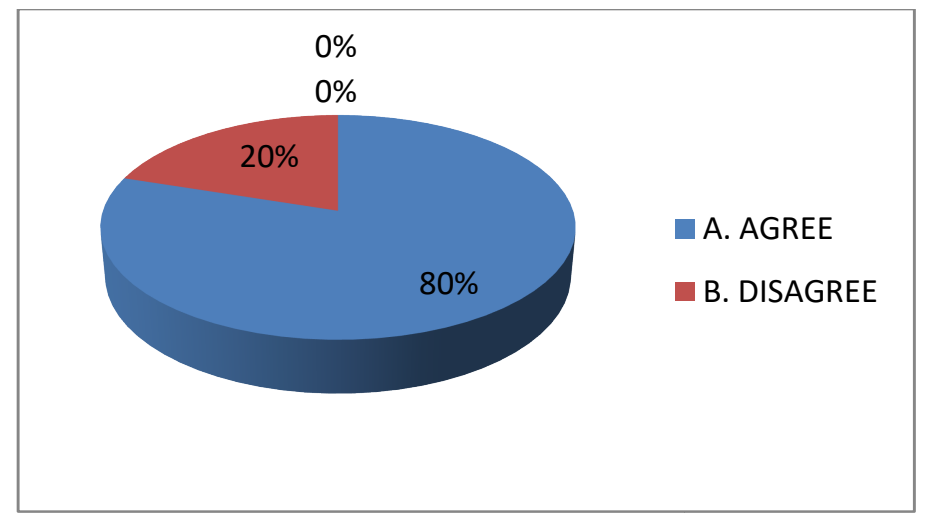

\section{Interpretation:}

From the above chart it can be analyzed that:

$20 \%$ of the employees do not agree that real basis of your problem identified

$80 \%$ of the employees agree real basis of your problem identified

4. Does your higher authority listen when your grievance presented?
A. YES
B. NO

\begin{tabular}{|l|l|}
\hline A. YES & 21 \\
\hline B. NO & 9 \\
\hline
\end{tabular}

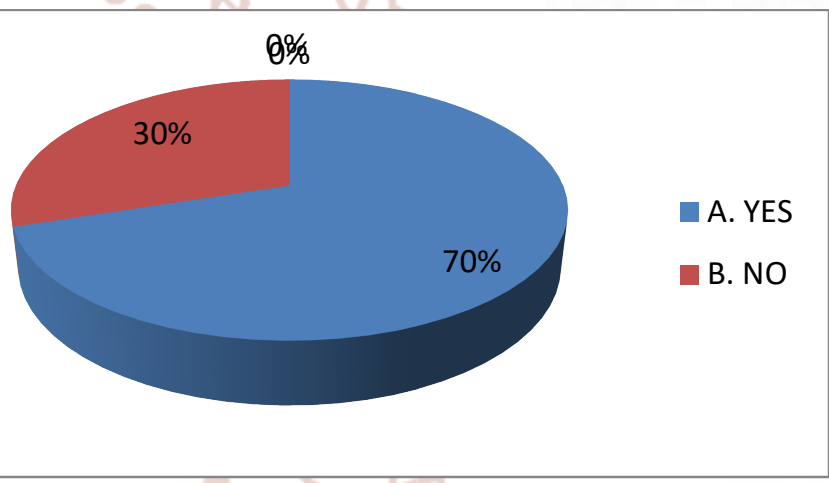

\section{Interpretation:}

From the above chart it can be analyzed that:

$30 \%$ of the employees do not agree that higher authority listen their grievance present

$70 \%$ of the employees say yes that higher authority listen their grievance presented

5. Is there regular follow up to ensure that the right decision has ended up in satisfaction?
A. Yes
B. No

\begin{tabular}{|l|l|}
\hline A. YES & 18 \\
\hline B. NO & 17 \\
\hline
\end{tabular}




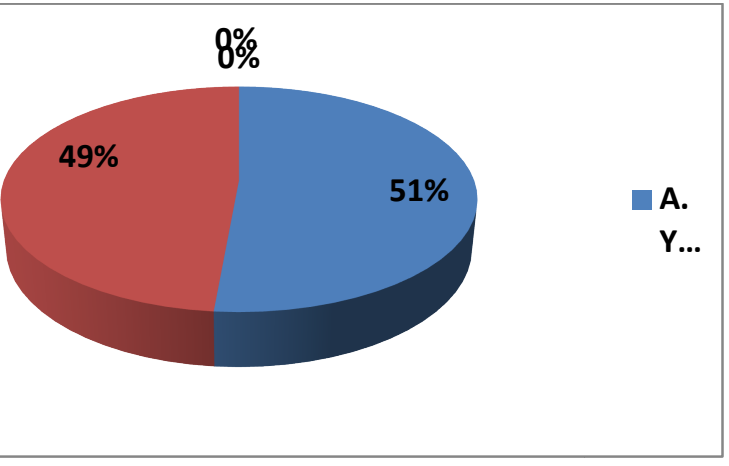

$17 \%$ of the employees say no that there is no temporary relief provided until proper decision is made so that it does not raise any adverse effects within the company

$83 \%$ of the employees say yes that there is temporary relief provided until proper decision is made so that it does not raise any adverse effects within the company

\section{Interpretation:}

From the above chart it can be analyzed that:

7. Do the committee members actively engage in resolving your problem?

$49 \%$ of the employees do not agree that there is regular follow up to ensure that the right decision

Has ended up in satisfaction

$51 \%$ of the employees do not agree that there is regular follow up to ensure that the right decision

Has ended up in satisfaction

6. Is there any temporary relief provided until proper decision is made so that it does not raise any adverse effects within the company?
A. Yes
B. No

\begin{tabular}{|l|l|}
\hline A. YES & 25 \\
\hline B. NO & 5 \\
\hline
\end{tabular}

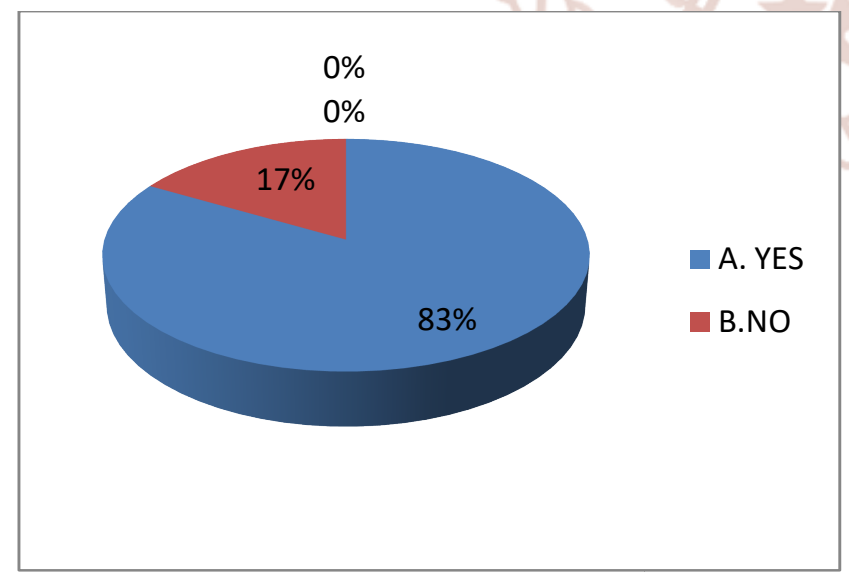

\section{Interpretation:}

From the above chart it can be analyzed that:

\section{Interpretation:}

From the above chart it can be analyzed that:

$53 \%$ of the employees say no that the committee members actively engage in resolving your problem

$47 \%$ of the employees say yes that the committee members actively engage in resolving your problem

8. If the decision is not satisfactory, are you given opportunity to take it to higher officials?
A. Yes
B. NO

\begin{tabular}{|l|l|}
\hline A. YES & 23 \\
\hline B. NO & 7 \\
\hline
\end{tabular}




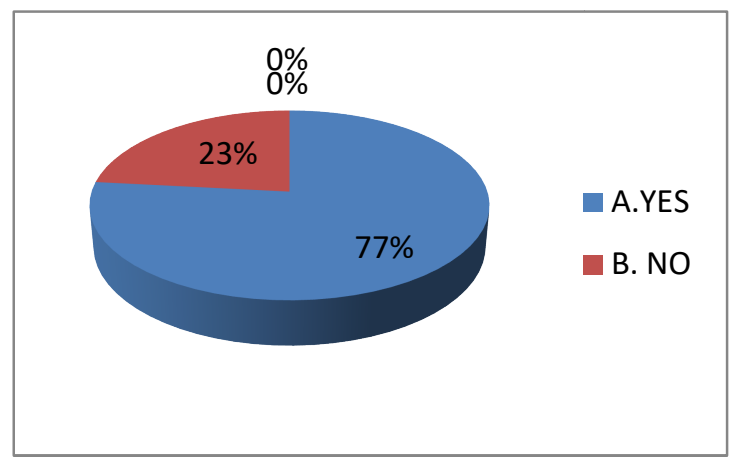

$80 \%$ of the employees say yes that there is authority given to the supervisor to resolve the problem

11. Are proper records maintained on each grievance?
A. Yes
B. NO

\begin{tabular}{|l|l|}
\hline A. Yes & 27 \\
\hline B. No & 3 \\
\hline
\end{tabular}

\section{Interpretation:}

From the above chart it can be analyzed that:

$23 \%$ of the employees say no if the decision is not satisfactory; there is no opportunity given to take it to higher officials

$77 \%$ of the employees say yes that if the decision is not satisfactory; there is an opportunity given to take it to higher officials

10. Is the supervisor given authority to take necessary action to resolve the problem?

\section{Interpretation:}

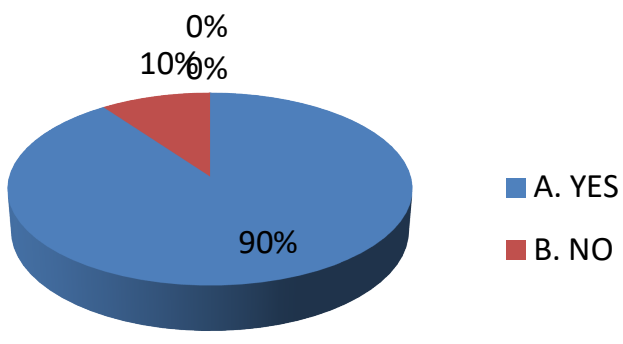
A. Yes
B. No

From the above chart it can be analyzed that:

$10 \%$ of the employees say no proper records maintained on each grievance

\begin{tabular}{|l|l|l|}
\hline A. YES & 24 \\
\hline B. NO & 6 \\
\hline
\end{tabular}

$90 \%$ of the employees say that proper records maintained on each grievance

12. Conflict resolving is an important function for the smooth functioning of an organization.

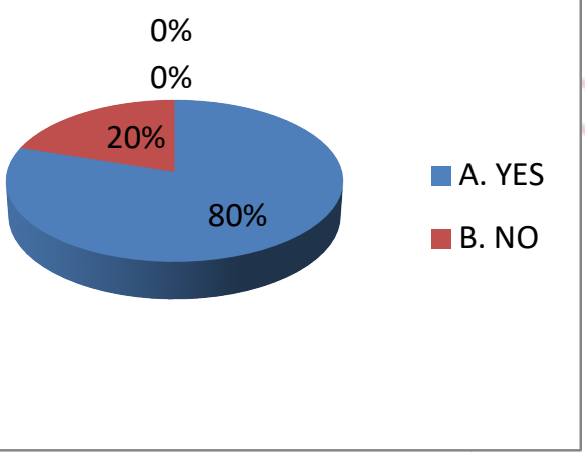

A. Agree

B. Disagree

\begin{tabular}{|l|l|}
\hline A. AGREE & 28 \\
\hline B. DISAGREE & 2 \\
\hline
\end{tabular}

\section{Interpretation:}

From the above chart it can be analyzed that:

$20 \%$ of the employees say no that there is no authority given to the supervisor to resolve the problem 


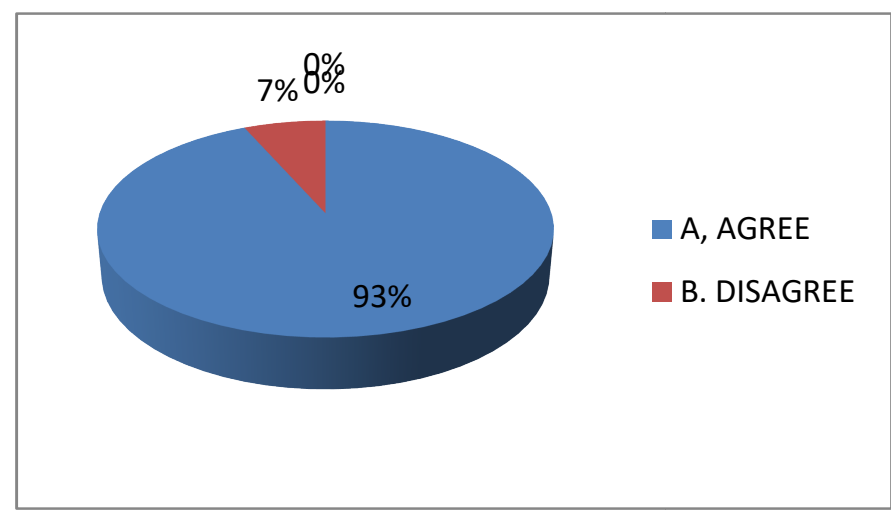

\section{Interpretation:}

From the above chart it can be analyzed that:

$7 \%$ the employees disagrees that Conflict resolving is an important function for the smooth functioning of an organization

$93 \%$ of the employees agree that Conflict resolving is an important function for the smooth functioning of an organization

\section{FINDINGS}

- $80 \%$ of employees have awareness about the grievance redressal committee of the company, its member and the monthly meeting held

- $80 \%$ of the employees agrees that real basis of problem is identified

- $70 \%$ of employees agree that higher authority listen when their grievances are presented

- $90 \%$ of the respondents say that proper records regarding grievances and confidentiality are maintained

- $83 \%$ of the employees say that temporary relief is provided until proper decision is made

\section{SUGGESTIONS}

- Employees and supervisor relation should be improved by arranging engagement programs.

- Informal counseling should be provided to address and manage the grievances at the workforce

- Regular informal meetings /discussions can be held for the employees.

- Communication Channel from down to up shall be encouraged.

\section{CONCLUSION}

The study reveals that the Grievance handling procedure is satisfactory

The organization is finding the significance of sustaining the employees and absorbing them. Additional developments can be made so that all members are extremely satisfied with the process. The ideas and recommendations when executed will still more benefit the organization. Most of the surveyed employees are contented with the process implemented by the organization for redressal of the grievances or complaints of the employees

\section{REFERENCES}

1. https://en.wikipedia.org/wiki/Grievance_(labour)

2. https://consumerhelpline.gov.in/about-portal.php

3. http://www.businessmanagementideas.com/human -resources-management/grievance-

handling/grievance-handling-procedure-stepsneed-and-elements/4618

4. https://grievances.maharashtra.gov.in/en 